\title{
Ozone: A review of recent experimental, clinical and epidemiological evidence, with notes on causation Part 1
}

\author{
DAVID V BATES MD FRCP FRCPC FACP FRSC \\ Department of Health Care and Epidemiology, University of British Columbia
}

DV BATES. Ozone: A review of recent experimental, clinical and epidemiological evidence, with notes on causation, Part 1. Can Respir J 1995;2(1):25-31.

Part 1 of this review is concerned with theoretical issues of ozone dosimetry, animal and cellular studies that illustrate the mechanism of action of orone on living tissues, and with clinical studies. Animal studies have indicated that there are long term effects from low level long term ozone exposure. Clinical studies involve controlled ozone exposures on human subjects, both normals and asthmatics. Exercise concomitant with the ozonc exposure increases the effect of the gas. It is concluded that the induction of an inflammatory response in the airway, both in the nose and in the lung, is the striking and earliest feature of orone exposure. Current unexplained observations include: the dissociation between the inflammatory and function test response; the mechanisms of 'adaptation' and of airway hyperresponsiveness; and the phenomena that underlic the effect of orone on maximal athetic pertormance.

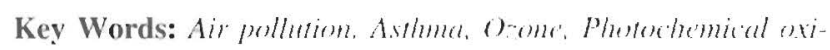
demis, Tropospherit arome
L'ozone : Une revue des données épidémiologiques, cliniques et expérimentales récentes accompagnée d'un commentaire sur la causalité

RÉSUMÉ : La première partic de cette revue porte sur des questions théoriques de dosimétrie de l'ozone, des ćtudes cellulaires et animales qui illustrent le mode d'action de l'ozone sur les tissus vivants et, des études cliniques. Les études animales démontrent que de faibles nivcaux d'exposition à long terme à l'ozone entrânent des effets à long terme. Les éludes cliniques comprennent des expositions contrôlées à l'ozone sur des sujets humains, sains et asthmatiques. L'exercice associé à une exposition à l'ozone accroît l'effè de ce gar. On conclut done yue l'induction de la réaction inllammatoire dans les voies aériennes, dans le nez ou le poumon. cst la caractéristique frappante et la plus précoce survenant après une exposition à lozone. Des observations courantes mais qui restent encore inexpliquées comprennent: la dissociation entre la réponse inflammatoire et les résultats des épreuves fonctionnelles; les mécanismes «d'adaptation» et d'hyperréaclivite bronchique et le phénomène sous-jacent à l'effet de l'ozone sur la performance athlétique maximale.
$\mathrm{T}$ HE BIBI.JOGRAPHY ON OZONE IS NOW SO I.ENGTHY, AND includes many hundreds of references to work published in the palst six years, that any summary has to be highly sclective. In this review, it is appropriate to emphasize some special aspects of orone that have to be understood if an informed evaluation of 'causality' is to be made. The effects of any pollutant have to be considered in relation to possible aculc effects on the one hand. and long term effects on the

Correspondence and reprints: Dr DV Bates, Department of Healh Care and Epidemiologs: Mather Bulding, 5804 Fairview Awenu', Vancouver, British Columbia V6T 1Z2. Telephone (604) 822-4530. Fur (60) t) 822-4(0).t 
other. Thus, in the case of sulphur dioxide, the special sensitivity of some asthmatics to this gals at very low concentration might play some part in explaining the epidemiological evidence of increased hospital attendances in relation to it; however, the question of whether living in a region with generally higher ambient sulphur dioxide levels increases the risk of developing chronic obstructive lung disease is obviously different - and is hardly likely to be explained by the first observation.

In the case of ozone, animal exposures are valuable in relation to mechanisms of action, although recent human experimentation using bronchial lavage and even bronchial biopsies have made this information lather less relevant than formerly. Animal exposure data are of more contemporary importance in relation to the possible effects of Ionger term exposures because controlled human clinical studies of that phenomenon are impratetical. Hence, in the following review, particularly close attention is paid to the eflects in animals shown to follow exposures lasting over weeks or months. In clinical terms, the complex questions involved in the multifactorial disease of 'asthma' have to be reviewed if the strengths and weaknesses of the prima facie case in relation to ozone atre to be appreciated. This is because, before a judgement of causality is altempted, not only must all collateral evidence have been reviewed, but the strengths of what may actually be tenuous linkages in the inferential argument must also be evalualed.

The question of "biological plausibility" in coming to a judgement of causality is complex. In the case of ozone, it requires consideration of dosimetry, of differences between animal species, and of the pathology and pathophysiology of common conditions such as asthmat.

These are the considerations that have determined the comparative emphasis in the following sections.

\section{ANIMAL AND CELLULAR STUDIES Ozone dosimetry}

A considerable body of work has been published in relation to ozone dosimetry (the dose delivered to different regions of the airway) during the past few years; only the major conclusions are summarized in this section:

- Although somewhat different kinetic assumptions and geometric airway data have been used, all the models indicate that in all species the tissue dose of inhaled ozone (expressed as $\mu \mathrm{g} / \mathrm{cm}^{2} / \mathrm{min} / \mu \mathrm{g}$ of inhaled ozone) reaches a maximum in the terminal bronchiolar region. The net dose is highest at the first point of impact. namely the trachea.

- The maximally affected zone, in terms of tissue dose. in the human and in the rat is the 17 th generation in the airway. For the human data, this calculation was based on a tidal volume of $800 \mathrm{~mL}$ and a breathing frequency of 15 breaths/min ( 1 ).

- The effect of exercise or increased ventilation is to increase the terminal bronchiolar regional dose slightly. and to increase significantly the pulmonary regional total dose and the dose in the proximal alveolar region.
- Differences among animal species have been considered in detail (2); discussion of these is beyond the scope of this review.

- Theoretical dosimetric calculations have been compared with measurements of ozone in the human respiratory tract under different conditions. Gerrity et al (3) measured ozone uptake in the extrathoracic airways of normal subjects and found that disappearance was als high :s $40 \%$ on inspiration, and $92 \%$ on both inspiration and expiration. Both of these values fell as respiratory rate was increased. A surprising finding was that there was only a small difference between the uptake that occurred with nose breathing and that with nouth breathing. Hynes et al (4) found little difference between nose and mouth breathing in pulmonary function response 10 orone.

These studies, taken as a whole, indicate that deposition modelling of inhaled ozone emphasizes the terminal bronchiolar and centriacinar regions as sites of maximal tissue deposition of the gas. Exercise, by increasing the lung volume and tidal volume and increasing the breathing fie quency, would be expected to increase the tissue dose significantly. These factors would be operative in addition to the higher dose delivered under these circumstances.

\section{Acute exposures}

The principal effects observed after acute exposures of : variety of species to ozone concentrations less than $1.0 \mathrm{ppm}$ are lung inflammation and changes in lung permeability (5-7) and increased airway responsiveness. There is increased mortality if the animal is subsequently challenged with at bacterial aerosol. The initial target of ozone appears to be lung fluid lining components and cell membranes (8). Reactive oxygen intermediates are involved in the cell damage, which is partly caused by atso-oxidation chain reactions. Increased permeability has been demonstrated after exposurc of rats to $0.12 \mathrm{ppm}$ or $0.4 \mathrm{ppm}$ for two days (9) or in guincil pigs exposed to $1.0 \mathrm{ppm}$ for $\mathrm{I} \mathrm{h}(10)$. The increased airway responsiveness is generally considered to be a consequence of the induced inflammation, and O'Byrne and colleagues (11) found that neutrophil depletion inhibited the increased airway responsiveness after ozone exposure in dogs. However, a recent series of experiments on at isolated rat lung preparation (12) showed that orone could increase airway responsiveness and damage airway epithclium in the absence of neutrophils before a microvascular leak was caused. The presence of neutrophils was shown to increase the magnitude of these effects of ozone.

The third effect, to increase mortality in mice if ozone exposure occurs before a bacterial alerosol is administered, is primarily due to its effect on macrophages. Recent experiments (1.3) using Streptencocus zoospidemicus in mice showed that $3 \mathrm{~h}$ of exposure to either 0.3 or 0.8 ppm ozone led to increased mortality, greatter in one strain of mice than in another. The difference in sensitivity was shown to be due to a difference in the sensitivity of the alveolar macrophages in the two different strains of mice. It is the phagocytic 
efficioncy of the macrophage that is impaired by the prior orone exposure.

Evidence that ozone impairs the clearance mechanism of the lung was provided by the observation that ozone exposures of base levels of $0.06 \mathrm{ppm}$ with daily excursions to 0.25 ppm in rats increased the retention of asbestos fibres (14). This was attributed to interference with macrophage function. Ozone exposure has also been shown to decrease the T lymphocyte and antiviral response (15).

Plopper et al (16) recently pointed out that nomhuman primates appear to be more responsive to ozone at concentrations less than $1.0 \mathrm{ppm}$ than are rats. This may be due 10 differences in nasal structure (and hence in delivered dose 10 the lung) or to differences in lung structure. since rats do not possess the many generations of respiratory bronchioles that exist in human and primate lungs.

This brief summary of the effects of acute animal exposures shown in animal experiments indicates that aggravation of inflammatory lesions, increased airway responsiveness and worsening of respiratory infections are effects that should he looked for in an exposed human population.

Other phenomena are described after acute ozone exposures to animals or to cells, usually to higher concentrations than those in ambient air. These include: changes in the nasal cavity and nasopharynx; assessments of the effects of the age of the rat on the outcome - in general younger rats seem more sensitive; no differences in effects between normal rats and rats with elastase-induced emphysema; studies of a wide range of biochemical effects, particularly on polyunsaturated fatty acids, antioxidants and proteins, and on the production of arachidonate metabolites; genotoxicity, mutagenicity and effects on carcinogenicity (although such effects can be shown, lor instance, on DNA [17], there is no human correlate); and cytogenetic studies showing effects with in vivo exposures to as little as 0.4 ppm ozone.

Witschi (18) recently reviewed these observations, pointing out that the radiomimetic alctivity of orone did make it a potential contributor to human lung cances.

\section{Long term exposures}

Human controlled exposures for longer than a few hours are not feasible; hence, the results of longer term animal exposures are very important. Since the primate lung appears to be more sensitive to ozone than the rat lung is, the evidence from primate exposures (Macaca fascicularis) will be considered first. Almost all of this work originated in the Primate Center in Davis, California. It was recently elegantly summarized and particularly well illustrated by this research group (19). The exposures were generally to $0.25 \mathrm{ppm}$ ozone for 8 h/day, seven days a week for 18 months. A very brief summary of their findings and conclusions follows:

- The initial inflammatory response is modified in subsequent exposures, but inflammatory cells in the peribronchiolar connective tissues persist during exposures that last up to one year.

- Epithelial and interstitial changes in distal airways are the most striking morphological changes in animals exposed for a year or more. There is a proliferation of nonciliated bronchiolar and type 2 alveolar epithelial cells. These changes start early and are evident after $50 \mathrm{~h}$ of exposure to $0.8 \mathrm{ppm}$ of ozone.

- Necrosis of ciliated and type 1 pneumocytes occurs, and these cells are replaced by the cells noted above. The long term effect is therefore a "remodelling' of the centriacinar airways by extension of bronchiolar cell types in airways thal were formerly alveolar ducts.

- There is an increase of collagen localized in the peribronchiolar and centriacinar regions. This confirms earlier studies from the same laboratory in rats exposed to higher concentrations of ozone.

- The morphological changes induced by the ozonc

exposure were still present after a six-month postexposure period of living in filtered air. Quantitalive morphology studies indicate that the lungs were more abnormal after the postexposure period than immediately after the ozone exposure.

Rat exposures of longer than two weeks have been studicd in a number of centres. Using a 78 -week exposure protocol of a base exposure of $0.06 \mathrm{ppm}$ with spikes $100.25 \mathrm{ppm}$. Chang et al (20) showed the following: that an acute response occurred in the centriacinar region, and that these changes partly resolved; that type 2 cells increased, and that the interstitium was increased; and that the basement membranc was thickened, but that centriacinar remodelling did not $o c-$ cur. Earlier observations from the same laboratory using a six-week exposure protocol of similar concentrations (21) noted that there was an increase in interstitium thickness and an increase in number of alveolar macrophages. Rat exposures to $0.95 \mathrm{ppm}$ for $8 \mathrm{~h} /$ daly for 90 days were found by Barr et al (22) to have resulted in airway remodelling, and the lesions resulting from chronic versus daily episodic exposures were similar (2.3).

Costa et al (24) demonstrated changes in lung function in rats after brief exposures, and more recently reported reductions in forced vital capacity (FVC) of rats after repetitive ozone exposures (25).

Saldiva el al (26) in Saro Parolo exposed (0) rats for six months to the ambient air and compared them with controls kept for the same length of time in a cleam area. $\triangle$ monitoring station $200 \mathrm{~m}$ from the exposure location showed that ozone went up to $0.4 \mathrm{ppm}$, particulates up to $00 \mu \mathrm{g} / \mathrm{m}^{3}$, sulphur dioxide up to $0.025 \mathrm{ppm}$ and carbon monoxide up to $4 \mathrm{ppm}$. The exposed rats had secretory cell hyperplasia in the airways, ultrastructural ciliary alterations and a more rigid mucus - changes that caused mucociliary clearance impairment. Nasal resistance and inflammatory cells in bronchoalveolar lavage (BAL) were also increased in the exposed group.

\section{Ozone in combination with other chemicals}

Since human exposures are rarely to a single pollutant, the question of interaction with other chemicals assumes some importance. In very detailed experiments on rats, Last (27) studied the effects of ozone and sulphuric acid aerosol alone and in combination. On all outcomes relatcd to an inflammat- 
tory response, the two were additive in their effects but were nol clearly synergistic. Nishikawa et al (28) studied the eflects of ozone and cigarette smoke in guinea pigs. They showed that airway responsiveness and permeability were affected when both irritants were inhaled, although single exposures to each separately at the same concentration produced no effect. This suggests that there may be al synergistic elfeet.

\section{CLINICAL STUDIES Effects on the nose}

Recent experinents have shown that after ozone exposure. changes in the nose detected by nasal lavage can be used as an indicutor of changes in the lung. Graham and Koren (29) exposed 10 normal subjects to air or $0.4 \mathrm{ppm}$ ozone for $2 \mathrm{~h}$ with exercise. Nasal lavage was perforned before, immediately after and $18 \mathrm{~h}$ alter exposure. BAL was also done at 18 h. Nasal polymorphonuclear neutrophils (PMN) increased 7.7-fold inmediately alter exposure and were still increased 6-fold at $18 \mathrm{~h}$, which wals identical to the increase in PMNs in BAL at this time. Albumin levels increased 3.9-fold in nasal lavage and 2.2-fold in BAL at $18 \mathrm{~h}$. Comparison ol the PMN data in nasal lavage and in BAL for eatch individual showed at significant quamlitative correlation after the atr exposure but not after ozone exposure.

Bascom et al (30) studied 12 asymptomatic subjects with a history of allergic rhinitis. They were exposed to $0.5 \mathrm{ppm}$ of ozone in an exposure chamber without exercise or to clean air as a control. Nasal challenge was performed with four doses of ragweed or grass antigen. Symptoms were ralled and nasal lavage was performed. Histamine and albumin concentrations were measured, and toxoid-antitoxoid mixture esterase activity and cell counts performed. Ozone caused a significant increase in upper and lower respiratory symptoms; a mixed inflammatory cell influx with a 7 -fold increase in nasal lavage neutrophils; a 20 -fold increase in eosinophils; a 10-fold increase in mononuclear cells; and an apparent sloughing of epithelial cells. Albumin concentration also increased. However, all of this did not increase the response to allergen.

Frischer et al (31) recently reported some field studies on the nose. Forty-four children were studied from May to October 1991. Each had five to eight lavages. One hundred and forty-eight nasal lavages were performed on 14 days following high ozone exposure (more than $180 \mu \mathrm{g} / \mathrm{m}^{3}$ or $90 \mathrm{ppb}$ ) and 106 after low exposures ( Icss than $40 \mu \mathrm{g} / \mathrm{m}^{3}$ or 7() $\mathrm{ppb})$. A significant increase in PMN counts occurred following high ozone datys $\left(27.38 \times 10^{3}\right.$ versus $\left.20.27 \times 10^{3}\right)$. Eosinophilic cationic protein also changed $(3.49 \mathrm{\mu g} / \mathrm{L}$ on low days and $5.39 \mu \mathrm{g} / \mathrm{L}$ on high days); myeloperoxidase also changed $(77.39 \mu \mathrm{g} / \mathrm{L}$ on low days and 138.6 on high ozone days). The authors concluded that "Ozone at ambient concentrations initiates a reversible inflammatory response of the upper airways in normal children".

McBride et al (32) recently reported on a comparison between the nasal inflammatory responses of normal and asthmatic subjects. Exposures using a head dome were to 120 or $240 \mathrm{ppb}$ of ozone or clean air for 9() mins with moderate exercise. They reported that the degree of inflammatory response, as judged by nasal lavage specimens, was considerably greater in the asthmatics, though pulmonary function test changes were not different between the two groups (and were minimal in degree).

\section{Effects on the normal lung}

Over the past 20 years, many human studies with controlled exposure to ozone have been reported. These are very briefly summarized here. It has been found that:

- FVC and forced expiratory volume in Is $\left(F E V_{1}\right)$ of young normal subjects is lowered by a 6 h exposure with exercise to as little as $0.08 \mathrm{ppm}$ of ozone (the current Canadian 1 h standard) (33).

- Considerable individual variation in response exists in normal subjects, but in a given individual, reproducibility is good. Hazucha (34) analyzed results from different laboratories involving a large number of normal subjects. He made the important observation that although one can talk of a 'threshold' value for an individual, there is no such thing as a threshold value for a group. This is because, if a statistically significant shift in mean value of a group is considered to be the criterion, then in one individual the value will have fallen very significantly as a result of the exposure. This point is often misunderstood.

- The first effect of ozone is not to cause airway constriction, but to limit the maximal inspiration the individual can take (probably through a spinal reflex ictivated by irritant receptor stimulation) (35).

- The decrement in lung function continues the longer the exposure, at least over $6 \mathrm{~h}(33)$.

- Over a $4 \mathrm{~h}$ period, an exposure regimen starting at $0 \mathrm{ppm}$, increasing to $0.24 \mathrm{ppm}$ at the maximum and declining to 0 ppm causes a greater change in FEV than a constant exposure to $0.12 \mathrm{ppm}$ for the whole period (36).

- When the FVC is lowered, airway inflammation is demonstrable. This was first shown by Seltzer et al (37) and confirmed in additional studies by Koren et al (38). A recent report from Aris et al (39) involved BAL in 12 normal subjects $\mathrm{I} 8 \mathrm{~h}$ after exposure to $0.20 \mathrm{ppm}$ ozone with moderate exercise. There was evidence of induced inflammation as shown by an increase in polymorphs and in inflammatory mediators. In addition, morphometric studies based on bronchial biopsy material showed a 6 -fold increase in neutrophils por $\mathrm{cm}^{2}$ of tissue from the bronchial wall. Koren et al ( 10$)$ recently summarized the time sequence of the inflammatory events in normal healthy subjects following a $2 \mathrm{~h}$ exposure to $0.4 \mathrm{ppm}$ ozone for $2 \mathrm{~h}$ with moderate exercise. At the end of the exposure, PMNs, prostaglandin E2 and interleukin- 6 were all increased in the BAL fluid and were at higher levels than they were $18 \mathrm{~h}$ later. Fibronectin and urokinase-type plasminogen activator, both of which have been associated with fibrogenic processes, were at higher levels in BAL ill 
$18 \mathrm{~h}$ than at $1 \mathrm{~h}$ after exposure. Prokin and tissue factor. which is derived from macrophages, were both increased similarly at $1 \mathrm{~h}$ and $18 \mathrm{~h}$ after exposure

These authors concluded: "It should be noted thal despitc the "reversibility" of spirometric changes after [ozone | exposure, there is strong evidence for the presence of lung inflammation even at $18 \mathrm{~h}$ after exposure".

Devlin et al (41) have compared the change in inflammatory indicators after different exposures; their results alre shown in Table 1.

In spite of this strong evidence, there is not a precise relationship between the function decrement induced by ozone and the degree of the inflammatory response $(42,43)$. There is unanimity that an inflammatory response may be found in some individuals with a minimal spirometric $r$ sponse, and lesser degrees of inflammation may occur in some with a considerable FVC decrement. These observaltions raise difficult questions in relation to attempts to set any protective standard.

- Ozone increases lung permeability as indicated by diethylenetriamine pentaacetic acid (DTPA) clearance (44)

- The decrement in lung function continues the longer the exposure, but repetitive exposures produce less of a response (this 'adaptation' appears to last for about 10 days). The most recent study of repetitive exposures is by Folinsbee and colleagues (45). Seventeen healthy males were exposed to 0.12 ppm ozone for $6.6 \mathrm{~h}$ on live consecutive days. They exercised (expired ventilation $39 \mathrm{~L} / \mathrm{min}$ ) for $50 \mathrm{mins}$ of each hour of exposure, except for a pause for lunch. Compared with air, the percentage changes in FEV 1 over the five days were $-12.8 \%$. $-8.7 \%,-2.5 \%,-0.06 \%$ and $+0.18 \%$. No increased response occurred on the second day of exposure. although previous data hid indicated that this might nceur. Airway responsiveness was increased after each exposure, and the ratios of methacholine responsiveness to control values were $2.22,3.67,4.55,3.99,3.24$ and 3.74 over the five days of testing. Thus, there was no attenuation of the induced increased airway responsiveness with consecutive exposures. In one normal subject, the ozone exposure did not increase airway responsiveness. Symptoms of cough and pain were present only on the first day. Nasal lavage revealed no increases in neutrophils except on the first ozone exposure day.

- Ozone exposure limits human maximal athletic performance (46). The mechanism of this is unclear because it seems unlikely to be due to an increase in airway resistance (47). Linder et al (48) reported that ozone exposure not only limits maximal oxygen uptake. but also shifts the anaerobic threshold. They studicd 1? men and 12 women during bicycle exercise until exhaustion in a climate controlled chamber. Ozone levels of $0.004,0.06$ to 0.07 and 0.12 to 0.13 ppm were used. In addition 10 the change in anaerobic threshold. ozone caused a cluar decrease in performance and in the
TABLE 1

Percentage change in inflammatory indicators following different exposures of ozone

\begin{tabular}{lccc}
\hline Inflammatory & \multicolumn{3}{c}{ Ozone exposure level (ppm) } \\
indicator & $\mathbf{0 . 4 0 ( 2 \mathrm { h } )}$ & $\mathbf{0 . 1 0}(6.6 \mathrm{~h})$ & $\mathbf{0 . 0 8}(\mathbf{6 . 6} \mathrm{h})$ \\
\hline Neutrophils & 720 & 379 & 210 \\
Fibronectin & 544 & 236 & 139 \\
Protein & 116 & 23 & 9 \\
PGE2 & 97 & 74 & 42 \\
LDH & $\mathrm{ND}$ & 58 & 41 \\
C3a & 72 & 15 & 29 \\
PA & 260 & 10 & 12 \\
Phagocytosis & $\mathrm{ND}$ & -24 & -21 \\
Alpha-1-AT & $\mathrm{ND}$ & 45 & 60 \\
IL-6 & $\mathrm{ND}$ & 393 & 155 \\
\hline
\end{tabular}

Alpha-1-AT Alpha- 1 antitrypsin; C3a Complement fragments: IL-6 Interleukin-6; LDH Lactate dehydrogenase; ND Not done; PA Plasminogen activator; PGE2 Prostaglandin: Phagocytosis (by macrophages). Data from reference 41

time that maximal work could be sustained. The mechanism of these effects is not precisely delineated: they may indicate that ventilation-perfusion mismatch in the lung has had the effect of lowering the arterial oxygen tension significantly. No direct measurements of arterial oxygen tension have been made however.

\section{Effects on asthmatics}

Early observations on asthmatics indicated that the percentage change in $\mathrm{FEV}_{1}$ for a given ozone exposure was not much different from that in nonasthmatics. However, when the datil are examined closely, it is clear that such a conclusion leads to an underestimation of the importance of the comparative effects. The recent observation that the nasal inflammatory response after ozone exposure is greater in asthmatic than in nonasthmatic subjects is noted ahove.

Kreit el al (49) studied nine asthmatic and ninc normal subjects (Table 2). Subjects were classified as asthmatic if they had a history of reversible chest lightness and whecoing, a previous diagnosis of asthma made by a plyysician. and a concentration of methacholine required to double baselinc specific airway resistance (PC100sRaw) of less than 1.5 $\mathrm{mg} / \mathrm{mL}$. All of these subjects were felt lo have relatively mild asthma. Their ages ranged from 2110.34 years: live were women and four were men. Baseline FEV I values varied from 2.58 to $5.32 \mathrm{~L}$. The nine normals were aged 19 10 31 years, and comprised five women and four men; all had normal methacholine responsiveness. An exposure chamber was used. Exercise was done on a hicycle ergometer with minute ventilations of about $50 \mathrm{~L} / \mathrm{min}$. Ozone concentrations were $0.4 \mathrm{ppm}$. With initial values of lung function $3010.40 \%$ lower in the asthmatics, the effects of a compurahle absolute fall in ventilatory indices are necessirily more signilicant in terms of limiting exercise capability or in causing dyspnca. The methacholine responsiveness changed in the normals from a pre-exposure value of $\left.32 .{ }^{4}\right) \mathrm{mg} / \mathrm{mL}$ (reguired 10 double airway resistance) to al posto/one value of $8.5 \mathrm{mg} / \mathrm{mL}$. In the 
TABLE 2

Changes induced by two-hour exposure to $0.4 \mathrm{ppm}$ ozone with intermittent exercise

\begin{tabular}{|c|c|c|c|c|c|c|}
\hline & FVC (L) & $F E V_{1}(L)$ & $\mathrm{FEV}_{1} / \mathrm{FVC} \%(\%)$ & FEF25-75 (L/s) & IC & sRaw \\
\hline Normals $(n=9)$ & -0.48 & -0.58 & -3.7 & -1.08 & -0.49 & +1.74 \\
\hline Mean initial values & 5.11 & 4.39 & 86.8 & 492 & 3.22 & 5.93 \\
\hline Asthma $(n=9)$ & -0.67 & -0.81 & -9.3 & -0.92 & -0.51 & +8.02 \\
\hline Mean initial values & 4.53 & 3.37 & 74.4 & 2.70 & 2.89 & 8.63 \\
\hline
\end{tabular}

FEF25-75 Maximal midexpiratory flow: FEV 1 Forced expiratory volume in $1 \mathrm{~s}$; FVC Forced vital capacity; IC Inspiratory capacity; sRaw Specific airway resistance. Data from reference 49

nine wishmatics, the pre-exposure value wass $0.52 \mathrm{mg} / \mathrm{mL}$, and after ozone it fell to $0.19 \mathrm{mg} / \mathrm{mL}$. Thus, although in each case there was approximatcly a 4-fold change in responsiveness, in the asthmatics it was from an initially hyperresponsive level.

- A low oronce exposure of 0.12 ppm breathed for I h at rest wass found by Molfino el al (50) to lead to at reduction in dose of inhaled allergen for a given response in six of seven asthmatics. It confirmed in larger scale studies, this would have important long tem implications. As noted above, Bascom et al (30) did not find that orone exposures enhanced the effect of an allergen in the nose, although an inflanmatory realction had been induced.

\section{Ozone in combination with other chemicals}

Although initial studies had indicated that ozone and sulphur dioxide breathed together might enhance the effect of eich, subsequent experiments failed to support this conclusion. Kuenig et al (51) showed that pre-exposure to ozone enhanced the effect of sulphur dioxide in a group of 13 adolescent asthmatics. The sequences of exposure studied were; air followed by $100 \mathrm{pph}$ sulphur dioxide; $120 \mathrm{ppb}$ ozone followed by $120 \mathrm{ppb}$ orone; and $120 \mathrm{ppb}$ ozone followed by 100 ppb sulphur dioxide. Air-sulphrur dioxide and ozone-ozone

\section{REFERENCES}

I. Overton JH, Milles IJ. Dosimetry modeling of inhaled toxic reactive gases. In: Watson AY, Bates RR, Kennedy D, eds, Air Pollution, the Autumobile, and Public Health. Washington: National Academy Press, I988.

2. Miller FJ, Overton JH. Critical issues in intra- and interspecies dosimetry of ozone. In: Schneider T, Lee SD, Wolters GJR, Grant LD, eds. Atmospheric O/one Research and its Policy Implications. Proceedings of the Third US-Dutch International Symposium, Nijmegen, May 1988. Amsterdam: Elsevier Sicince Publishers, 1988

3. Girlity TR, Weaver RA, Berntsen J, House DE, O'Neil JJ. Extrathoracic and intrathoracic removal of $\mathrm{O}_{3}$ in tidal-breathing humans. J Appl Physiol 1988;65:393-400.

4. Hynes B, Silverman F, Cole P, Corey P. Effects of ozone exposure: a comparison between oral and nasal breathing. Arch Environ Health 1988:43:357-60.

5. Holtzman MJ, Fabbri LM, O'Byrne PM, et al. Importance of airway inflammation for hyperresponsiveness induced by ozone. Am Rev Respir Dis 1983;127:686-90.

6. Holtzman MJ, Fabbri LM, Skoogh BE, et al. Time course of airway hyperresponsiveness induced by ozone in dogs. $\mathrm{J}$ Appl Physiol 1983;55:1232-6.

7. Fabbri LM, Aizawa H, Alpert SE, et al. Airway hyperresponsiveness and changes in cell counts in bronchoalveolar exposures did not cause signilicant changes in function, but ozone-sulphur dioxide exposure citused an $8 \%$ fall in FEV 1 , a. $19 \%$ increase in respiratory resistance, and a $15 \%$ decrease in $V_{\max } 50 \%$

\section{CONCLUSIONS}

There is a wealth of experimental data on the acule elfects of orone on the human subject. The first phenomenon observed is the induction of inflammation. Decrements in lung function are complex in origin, and may not follow closely the severity of the inflammation induced. There are many poorly understood phenomena, including the precise determinants of the individual response: the mechanism of adapt:tion"; the phenomena that underlie the observed reduction in maximal oxygen uptake; and the consequences of ozone exposure in combination with other irritants. There is evidence that asthmatic subjects may have a greater inflammatory response than nonasthmatics. Although the degree of function test response is broadly similar between normals and :tsthmatics, the latter may be more severely affected because their initial pulmonary function may be lower, and their pre-exposure degree of airway responsiveness is greater.

ACKNOWLEDGEMENTS: This review was completed under a contract (No 4346) with Health and Welfare Canada.

lavage after ozone exposure in dogs. Am Rev Respir Dis 1984; I29:288-91

8. Pryor WA, Das B, Church DF. The ozonation of unsaturaled fatty acids: aldehydes and hydrogen peroxide as products and possible mediators of ozone toxicity. Chem Res Toxicol 1991;4:34I-8.

9. Guth DJ, Warren DL, Last JA. Comparative sensitivity of measurements of lung damage made by bronchoalveolar livage after short-term exposure of tats to orone. Toxicology [) $86: 40: 131-44$

10. Miller PD, Gordon T, Warnick M, Andur MO. Erflect of usomc and histamine on airway permeability to horseradish peroxidase in guinea pigs. $\mathbf{J}$ Toxicol Environ Health 1986; 18:121-32

11. O'Byrne PM, Walters EH, Gold BD, et al. Neutrophil depletion inhibits airway hyperresponsiveness induced by ozone exposure. Am Rev Respir Dis 1984;130:214-4.

12. Joad JP, Bric JM, Pino MV, Hyde DM, McDonald RJ. Effects of ozone and neutrophils on function and morphology of the isolated rat lung. Am Rev Respir Dis 1993; 147:1578-84.

13. Gilmour MI, Park P, Selgrade MK. Ozone-enhanced pulmonary infection with Streptococcus zooepidemicus in mice. Am Rev Respir Dis 1993:147:753-60.

I t. Pinkerton KE, Brody AR, Miller FJ, Crapo JD. Exposure (o) losv levels of ozone results in enhanced pulmonaty retention of 
inhaled asthestos fibers. Am Rev Respir Dis 1989;140:1075-81.

15. Jakab GJ, Hmieleski RR. Reduction of influenza virus pathogenesis by exposure $100.5 \mathrm{ppm}$ ozone. I Toxicol Environ Health 1988;23:455-72.

16. Plopper CG, Harkema JR, Last JA, et al. The respiratory system of nonhuman primates responds nore to ambient concentrations of ozone than does that of rats. In: Berglund RL, Lawson DR, McKee DJ, eds. Tropospheric Ozone and the Environment: Papers from an International Conference, Los Angeles, March 1990. Pittsburgh: Air \& Waste Management Association, 1990.

17. Hamelin C. Production of single- and double-strand breaks in plasmid DNA by ozone. Int J Radiat Oncol Biol Phys 1985;11:253-7.

18. Witschi H. Ozone, nitrogen dioxide, and lung cancer: a review of some recent issues and problems. Toxicology 1988;48:1-20.

19. Tyler WS, Julian MD, Hyde DM. Respiratory bronchiolitis following exposures to pholochemical air pollutants. Semin Respir Med 1992;13:94-113.

20. Chang L-Y, Huang Y, Stockstill BL, et al. Epithelial injury and interstitial fibrosis in the proximal alveolar regions of rats chronically exposed to a simulated pattern of urban ambient ozone. Toxicol Appl Pharmacol 1992;115:241-52.

21. Barry BE, Miller FJ, Crapo JD. Effects of inhalation of 0.12 and 0.25 parts per million ozone on the proximal alveolar region of juvenile and adult rats. Lab Invest 1988;53:692-7()4

22. Barr BC, Hyde DM, Plopper CG, Dungworth DL. Distal airway remodelling in rats chronically exposed to ozone. Am Rev Respir Dis 1988;137:924-38.

23. Barr BC, Hyde DM, Plopper CG, Dungworth DL. A comparison of terminal airway remodelling in chronic daily versus episodic ozone exposure. Toxicol Appl Pharmacol 1990;106:384-407.

24. Costa DL, Hatch GE, Highfill J, Stevens MA, Tepper JS. Pulmonary function studies in the rat addressing concentration versus time relationships in ozone. In: Schneider T, Lee SD, Wolters GJR, Grant LD, eds. Atmospheric Ozone Research and its Policy Implications: Proceedings of the Third US-Dutch International Symposium, Nijmegen, May 1988. Amsterdam: Elsevier Science Publishers, 1988.

25. Costa DL, Tepper JS, Stevens MA, Fitzgerald S, Last JA. Functional evidence of a restrictive lung lesion in rats after chronic exposure to a simulated urban prolite of ozone. (In press)

26. Saldiva PHN, King M, Delmonte VLC, et al. Respiratory alterations due to urban air pollution: an experimental study in rats. Environ Research 1992:57:19-33.

27. Last JA. Synergistic effects of air pollutants: o/one plus a respirable aerosol. Health Effects Institute Research Report 1990;38.

28. Nishikawa M, Ikeda H, Nishiyama H, Yamakawil II, Suzuki S. Okubo T. Combined effects of ozone and cigarette smoke on dirwaly responsiveness and vascular permeability in guineal pigs. Lung 1992;170:31 1-22.

29. Graham DE, Koren HS. Biomarkers of inflammation in ozone-exposed humans. Am Rev Respir Dis 1990; 142:152-6.

30. Bascom R, Naclerio RM, Fitzgerald K, Kagey-Sobotka A. Proud D. Effect of ozone inhalation on the response to nasal challenge with antigen of allergic subjects. Am Rev Respir Dis 1990:142:594-601.

31. Frischer TM, Kuehr J, Pullwit A. et al. Ambient ozone causes upper airways inflammation in children. Am Rev Respir Dis 1993;148:961-4.

32. McBride DE, Koenig JQ, L uchtel DL, Williams PV. Henderson WR Jr. Inflammatory effects of ozone in the upper airways of subjects with asthma. An I Respir Crit Care Med
1994:149:1192-7.

33. Horstman DH, Folinsbe LJ, Ives PJ, Abdul-Saliam S. McDonnell WF. Ozone concentration and pulmonary response relationships for 6.6-hour exposures with live hours of moderate exercise to $(0.08,0.10$, and $0.12 \mathrm{ppm}$. Am Rev Respir Dis $1990 ; 142: 1158-63$

34. Hazucha M. Relationship between orone exposure and pulmonary function changes. J Appl Physiol 1087:62:1671-80.

35. Hazucha M, Bates DV, Bromberg P. Mechanism of action of ozone on the human lung. J Appl Physiol 1089;67:1535-41.

36. Hazucha MJ, Seal E, Folinsbee L. Effects of steady-state and variable ozone concentration profiles on pulmonary function in man. Am Rev Respir Dis 1990:141:A71.

37. Seltzer J, Bigby BG, Stulberg M, et al. O3-induced change in bronchial reactivity to methacholine and airway inflammation in humans. J Appl Physiol 1986:60;:1321-6

38. Koren HS, Devlin RB, Graham Dl; et al. Orone-induced inflammation in the lower airways of human subjects. Am Rev Respir Dis 1989;139:407-15.

39. Aris RM, Christian D, Hearne PQ, Kerr K, Finkbeiner WI: Balmes JR. Ozone-induced airway inflammation in human subjects as determined by airway lavage and biopsy. Am Rev Respir Dis 1993;148:1363-72.

40. Koren HS, Devlin RB, Becker S. Perey R, McDonnell WF. Time-dependent changes of markers alssociated with inflammation in the lungs of humans exposed to ambient levels of ozone. Toxicol Pathol 1991;19:406-11.

41. Devlin RB, McDonnell WF. Mann R, et al. Exposure of humans to ambient levels of orone for 6.6 hours causes cellular and biochemical changes in the lung. $A \mathrm{~m} \mathrm{~J}$ Respir Cell $\mathrm{Mol}$ Biol 1991;4:72-81.

42. Scannell CH., Aris R, Christian D, et al. Ozone-induced airway inflammation is not correlated with physiological responses. Am J Respir Crit Care Med 1994:149:A150.

43. Frampton MW, Voter KZ, Fogarty JP, et al. Airway inflammation and functional responsiveness to ozone in humans. Am J Respir Crit Care Med 1994;149:A150.

44. Kchrl HR, Vincent LM, Kowalsky R.l, el al. Ozone exposure increases human respiratory epithelial permeability in humans. Am Rev Respir Dis 1987:135:1 124-8.

45. Folinsbee LJ, Horstman DH, Kchrl HR, Harder S. Abdul-Salaam S, Ives PJ. Respiratory responses to repeated prolonged exposure to 0.12 ppm ozone. Am J Respir Crit Care Med 1994;149:98-105.

46. Folinsbee LJ, Silverman F. Shephard R.I. Decrease of maximum work performance following ozone cxposure. J Appl Physiol: Respirat Environ Exercise Physiol 1977;42:531-6.

47. Bates DV. Effects of irritant gases on maximal exercise performance. In: Cerretelli P, Whipp BJ, eds. Exercisc Bioenergetics and Gas Exchange. Amsterdam: Elsevier/North Holland Biomedical Press, 1980

48. Linder J, Herren D, Monn C, Wanner H-U. Die Wirkung von Ozon auf die koerperliche Leistungsfachigkeit. Schweiz Z Sportmed 1988;36:5-10

49. Kreit JW. Gross KB, Moore TB, Lorenzen TJ, D'Arcy J. Eschenhacher WL. Ozone-induced changes in pulnonary function and bronchial responsiveness in asthmatics. J Appl Physiol 1989:66:217-22.

50. Molfino NA, Wright SC, Katz I, et al. Effect of low concentrations of ozone on inhaled allergen responses in asthmatic subjects. Lancet 1991:338:199-203.

51. Koenig JQ. Covert DS, Hanley QS, Van Belle G. Pierson WE. Prior exposure to ozone potentiates subsequent response to sulfur dioxide in adolescent asthmatic subjects. Am Rev Respir Dis 1990):141:377-80. 


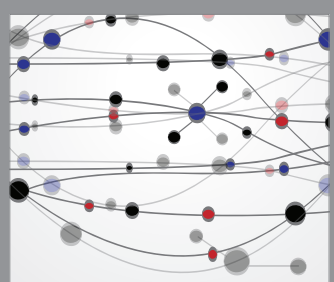

The Scientific World Journal
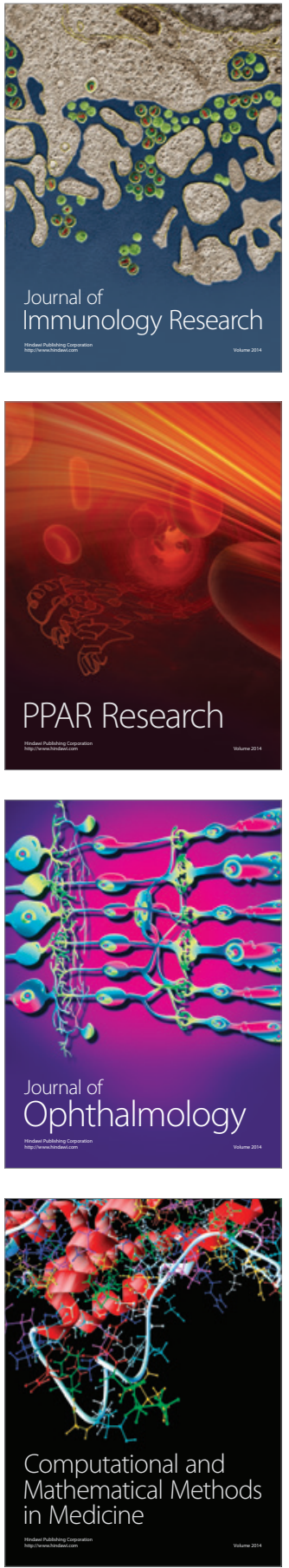

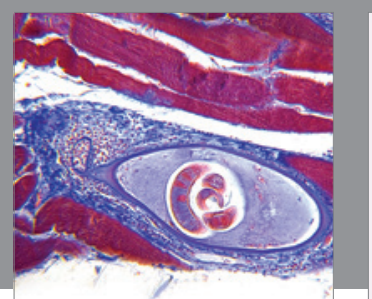

Gastroenterology Research and Practice

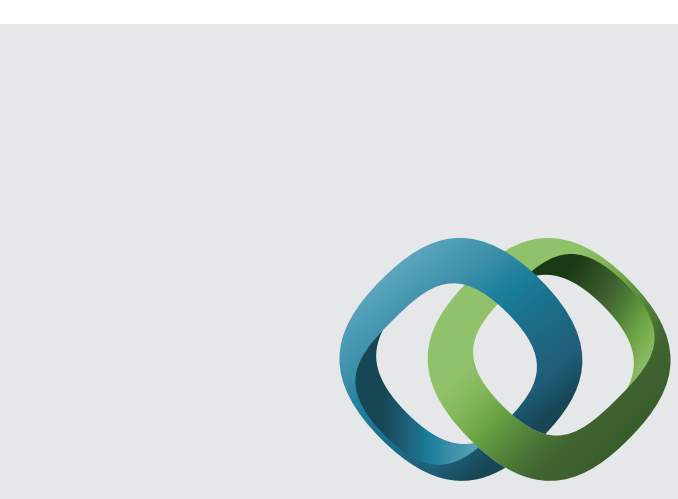

\section{Hindawi}

Submit your manuscripts at

http://www.hindawi.com
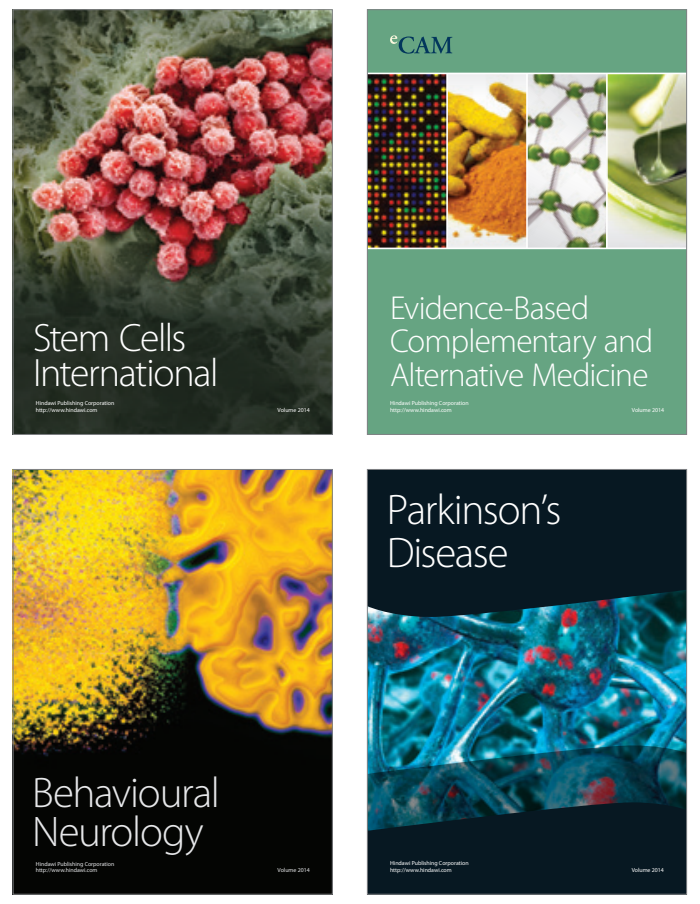
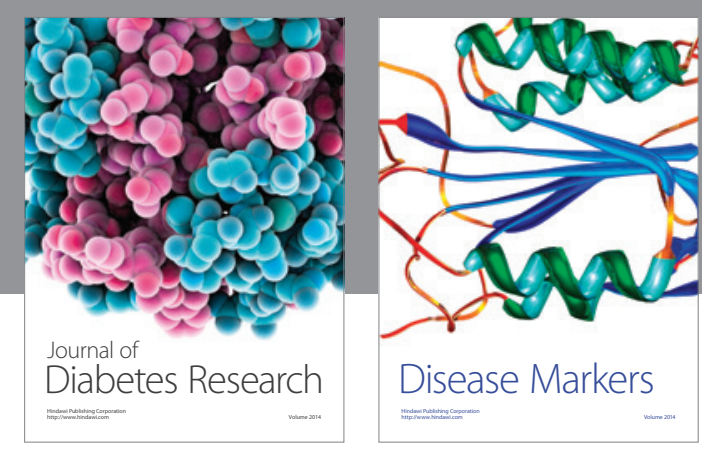

Disease Markers
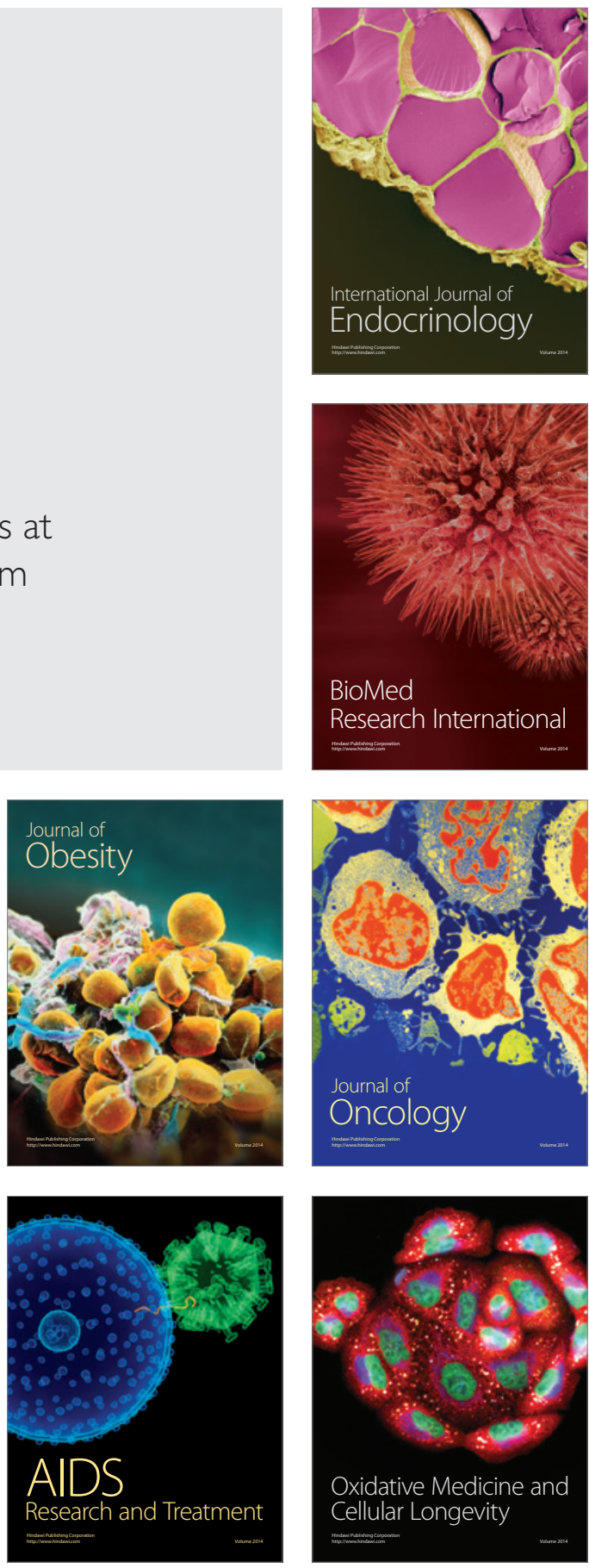